\title{
World's first report of Erysiphe hyperici causing powdery mildew on fenugreek
}

\author{
A.U. Gojiya, J. R. Pandya* and C. V. Kapadia ${ }^{1}$
}

Department of Plant Pathology, N.M. College of Agriculture, Navsari Agricultural University, Navsari (Gujarat) India ${ }^{1}$ Department of Plant Molecular Biology and Biotechnology, ASPEE College of Horticulture and Forestry, Navsari Agricultural University, Navsari (Gujarat) India

\section{ARITCLE INFO}

Received : 21.01 .2018

Accepted : 30.09 .2018

*Corresponding author:

jrpandya@nau.in
KEY WORDS : Erysiphe hyperici causing, Powdery mildew, Fenugreek

How to view point the article : Gojiya, A.U., Pandya, J.R. and Kapadia, C.V. (2018). World's first report of Erysiphe hyperici causing powdery mildew on fenugreek. Internat. J. Plant Protec., 11(2) : 174-176, DOI : 10.15740/HAS/IJPP/11.2/174-176, Copyright@ 2018: Hind Agri-Horticultural Society.

\section{INTRODUCTION}

Powdery mildew disease was observed on fenugreek (Trigonella foenum-groecum L.) in the farm of Navsari Agricultural University, Navsari, Gujarat during the year 2015. Subsequently, disease has been observed covering wide area in the winter of year 2016 and 2017. Infection starts on the leaves as a small round to irregular powdery mycelia which gradually increases in the size and merge covering the entire leave (Fig. 1). All the above ground parts of the plant including petiole, stem and pod were covered with the white colored powdery mass of the mycelium and conidia within 15-20 days (Fig. 2). Early infected plant remained dwarf bearing very few pods either empty of bearing few small size shriveled grains of no significance. Infection occurs on both the surface of the leaf, however, higher colonization was seen on adaxial surface. Pathogenicity test was proved by gently pressing the adaxial surface of an infected leaf with abundant sporulation onto the adaxial surface of a healthy leaf of 45 days old fenugreek (cv. LOCAL) plants grown at $25^{\circ} \mathrm{C}$. Inoculated and control plants were covered with 50 micron clear polyethylene bags for $48 \mathrm{~h}$ after inoculation. Symptoms observed after a week was consistent with the originally infected field plants, while no symptoms were observed on the control plants. Microscopic observation revealed that the pathogen growing on the inoculated plants was consistent with the morphology of the original fungus.

The conidiophores were 13.80-18.37 $\mu \mathrm{m}$ long, whereas the width from the widest part of conidiophores was 4.96-7.04 $\mu \mathrm{m}$. Hyaline conidia developed in acropetal succession were ellipsoid in shape with 29.25-39.92 $\mu \mathrm{m}$ length and 11.74-19.37 $\mu \mathrm{m}$ width. Fibrosin bodies in conidia were not found. Conidial cell wall showed evidence of faint reticulation (Fig. 3). Similar conidial morphology of the conidiophores with conidia was 